\title{
Pengaruh Model Pembelajaran Kooperatif Tipe Student Teams Achievement Division (STAD) Terhadap Hasil Belajar Passing Sepakbola
}

 \\ ${ }^{123}$ Universitas Pendidikan Ganesha \\ *Corresponding author: ahmadmuhlisin0426@gmail.com
}

\begin{abstract}
Abstrak
Rendahnya aktifitas belajar siswa yang disebabkan oleh metode pembelajarn yang digunakan guru cenderung monoton menyebabkan hasil belajar siswa kurang optimal. Penelitian ini bertujuan untuk mengetahui pengaruh model pembelajaran kooperatif tipe STAD terhadap hasil belajar teknik dasar passing menggunakan kaki bagian dalam dan luar dalam permainan sepakbola. Jenis penelitian adalah eksperimen sungguhan (true experimental) dengan rancangan Post Test Only Control Group Design. Populasi penelitian ini adalah seluruh siswa kelas berjumlah 5 kelas dengan populasi 170 orang. Pengambilan sampel yang digunakan simple random sampling. Data hasil belajar dikumpulkan melalui tes urian dan unjuk kerja. Analisis data menggunakan uji-t dengan taraf signifikan signifikansi $\alpha=0.05$. Data penelitian menunjukkan rata-rata gain skor ternormalisasi pada kelompok eksperimen adalah 77,00, dengan standar deviasi 14.36, sedangkan rata-rata kelompok kontrol adalah 60.00, dengan standar deviasi 16.50. Data berdistribusi normal dan homogen. Hasil uji hipotesis diperoleh melalui uji parametrik (uji Independent Samples Test) adalah $0.003<0.05$. Berdasarkan analisis data dan pembahasan disimpulkan bahwa model pembelajaran kooperatif STAD berpengaruh signifikan terhadap hasil belajar teknik dasar passing kaki bagian dalam dan luar. Disarankan untuk guru PJOK dapat menerapkan model pembelajaran kooperatif tipe STAD karena terbukti berpengaruh terhadap hasil belajar sisiwa.
\end{abstract}

Kata Kunci : Model pembelajaran STAD, hasil teknik dasar passing sepakbola

\section{Abstract}

The low student learning activities caused by the learning methods used by the teacher tend to be monotonous, causing student learning outcomes to be less than optimal. This study aims to determine the effect of the STAD type cooperative learning model on learning outcomes of basic passing techniques using the inside and outside of the foot in soccer games. This type of research is a real experiment (true experimental) with a Post Test Only Control Group Design. The population of this study was all students in 5 classes with a population of 170 students. Sampling used simple random sampling. Learning outcomes data were collected through essay tests and performance tests. Data analysis used a t-test with a significance level of $=0.05$. The research data shows that the average normalized score gain in the experimental group is 77.00 , with a standard deviation of 14.36 , while the control group's average is 60.00 , with a standard deviation of 16.50 . The data are normally distributed and homogeneous. The results of hypothesis testing obtained through parametric testing (Independent Samples Test) were $0.003<0.05$. Data analysis and discussion concluded that the STAD cooperative learning model had a significant effect on learning outcomes of the basic inner and outer leg passing techniques. It is recommended that PJOK teachers apply the STAD type cooperative learning model because it has been proven to affect student learning outcomes.

Keywords: STAD learning model, the results of the basic football passing techniques

$\begin{array}{ll}\text { History: } & \text { Publisher: Undiksha Press } \\ \text { Received: 03 Oktober } 2021 & \text { Licensed: This work is licensed under } \\ \text { Revised: } 29 \text { Oktober } 2021 & \text { a Creative Commons Attribution 3.0 License } \\ \text { Accepted: } 01 \text { November } 2021 & \text { CC } \\ \text { Published: } 25 \text { November } 2021 & \text { SA }\end{array}$




\section{Pendahuluan}

Pendidikan merupakan bagian yang sangat penting dalam kehidupan manusia. Karena pendidikan adalah salah satu kewajiban yang harus dilaksanakan oleh setiap warga Negara guna meningkatkan kualitas hidupnya (Aini \& Taufiq, 2018). Tujuan pendidikan adalah untuk mempersiapkan generasi bangsa dengan wawasan pengetahuan yang tinggi dan membentuk watak yang bermanfaat dalam mencerdaskan kehidupan bangsa dan Negara (Suryanti, Kristiantari, \& Suadnyana, 2016 ; Ngubaidillah, 2018). Untuk mewujudkan SDM yang berkualiatas serta fungsi dan tujuan dari pendidikan nasional maka diperlukan suatu kesatuan yang utuh antara komponen-komponen dalam suatu sistem disetiap satuan pendidikan untuk membentuk kualitas individu yang unggul dalam segala bidang, maka sangat dibutuhkan peran dari masing-masing mata pelajaran yang diajarkan di sekolah kepada peserta didik untuk mencapai tujuan dari pendidikan nasional. Tidak terkecuali salah satunya dengan pembelajaran Pendidikan Jasmani.

Pendidikan jasmani adalah suatu aktifitas gerak yang menyangkut kemampuan fisik dalam pembelajarannya (Jessicasari \& Hartati, 2014; Qomarrullah, 2015; Setiawan, 2017; Setiawan \& Rahmat, 2018; Wicaksono \& Hendityo, 2019). Melalui pendidikan jasmani manusia dapat belajar lebih banyak hal yang berhubungan dengan afektif, kongnitif, dan psikomotor yang merupakan bekal manusia untuk mencapai tujuan hidup (Hanief \& Sugito, 2015; Paramitha, 2018). Pendidikan Jasmani melibatkan aktivitas fisik dan kesehatan untuk menghasilkan perubahan holistic dalam kualitas individu, baik dalam hal fisik, mental serta emosional (Hasan, 2015). Jadi dapat disimpulkan pendidikan jasmani merupakan bagian integral dari sistem pendidikan secara keseluruhan, bertujuan untuk mengembangkan aspek kesehatan, kebugaran jasmani, ketrampilan berfikir kritis, stabilitas emosional, ketrampilan sosial, penalaran dan tindakan moral melalui aktivitas jasmani dan olahraga.

Pendidikan Jasmani yang diajarkan di sekolah memiliki peranan sangat penting, karena dapat memberikan kesempatan kepada peserta didik untuk terlibat langsung dalam berbagai pengalaman belajar melalui aktivitas jasmani yang dilakukan secara sistematis. Oleh karena itu penting menciptakan proses pembelajaran yang efektif dan menyenangkan. Pembelajaran adalah proses interaksi peserta didik dengan pendidik dan sumber belajar pada suatu lingkungan belajar. Pembelajaran merupakan bantuan yang diberikan pendidik agar dapat terjadi proses perolehan ilmu dan pengetahuan, penguasaan kemahiran dan tabiat, serta pembentukan sikap dan kepercayaan pada peserta didik. Oleh karena itu proses pembelajaran harus dirancang untuk mampu mengembangkan hasil belajar yang diperlukan dimensi jangka panjang yang dapat membekali siswa dalam kehidupan dan belajar sepanjang hayat, yaitu kemampuan berpikir, kecakapan hidup, psikomotor, dan sudah barang tentu hasil belajar. Pada proses pembelajaran, guru tidak cukup hanya berbekal pengetahuan berkenaan dengan bidang studi yang diajarkan, akan tetapi perlu memperhatikan aspek-aspek pembelajaran yang mendukung terwujudnya pengembangan potensi peserta didik. Guru harus mampu menggunakan metode pembelajran yang sesuai dengan materi yang sedang diajarkan serta mampu membangkitkan motivasi serta minat siswa untuk mengikuti proses pembelajran tersebut.

Permasalahan yang masih dijumpai dalam pembelajaran pendidikan jasmani, olahraga dan kesehatan (PJOK) salah satunya adalah rendahnya aktifitas belajar siswa sehingga hasil belajar siswa kurang tercapai optimal. Keberhasilan proses belajar tidak terlepas dari cara guru mengajar, seorang guru harus mampu menciptakan suasana belajar yang menarik bagi siswanya dan waktu yang digunakan oleh guru harus efektif dan efisien untuk menyampaikan materi pembelajaran. Pembelajaran yang diberikan oleh guru harus dikemas dengan menarik sehingga siswa memiliki minat untuk mengikuti pembelajaran. 
Namun pada kenyataannya hasil belajar teknik passing sepakbola mengunakan kaki bagian dalam belum sesuai seperti yang diharapkan. Hal ini diketahui dari hasil wawancara dan observasi di SMP Negeri 4 Sukasada yang peneliti laksanakan pada tahun 2018. Hasil wawancara yang diperoleh dari guru PJOK yang bernama Nyoman Kartana, 1) kurangnya pemahaman siswa terhadap teknik Passing Sepakbola menggunakan kaki bagian dalam, 2) kurangnya minat siswa dalam mengikuti pembelajaran PJOK, khususnya teknik Passing Sepakbola menggunakan kaki bagian dalam, 3) rendahnya nilai siswa dalam pembelajaran PJOK khususnya teknik passing sepakbola menggunakan kaki bagian dalam. Selanjutnya berdasarkan hasil pengamatan yang dilakukan dilapangan, dalam proses pembelajaran sepakbola terlihat masih banyak siswa yang belum menguasai ketiga teknik permainan sepakbola, paling terlihat yaitu pada teknik Passing Sepakbola menggunakan kaki bagian dalam, dan pada saat guru mengajar teknik passing guru masih menggunakan metode ceramah sehingga pembelajaran masih berpusat pada guru (teacher centered) serta kurangnya pembelajaran inovatif yang melibatkan siswa dalam proses pembelajaran.

Berdasarkan nilai harian siswa yang peneliti peroleh mengenai hasil belajar dari guru PJOK kelas VII SMP Negeri 4 Sukasada tahun pelajaran 2019/2020 mengenai proses pembelajaran PJOK materi passing sepakbola, bahwa dari hasil ulangan harian meteri passing bola besar (Sepakbola) kelas VII masih banyak ditemukan siswa yang belum memenuhi Kreteria Ketuntasan Minimal (KKM). Jika keadaan ini berlangsung secara terus menerus tentu akan berpengaruh terhadap tujuan dari pendidikan jasmani itu sendiri, serta minat dan motivasi siswa dalam mengkuti pembeljaran Pendidikan Jasmani akan ikut menurun.

Berdasarkan permasalahan tersebut, peneliti mencoba memberikan alternatif pemecahan masalah yaitu dengan menggunakan model pembelajaran kooperatif tipe student teams achievement divisoan (STAD) dalam pembelajaran PJOK pada materi teknik passing sepakbola menggunakan kaki bagian dalam. Model pembelajaran berfungsi sebagai pedoman bagi para perancang pembelajaran dan para guru dalam merencanakan aktivitas belajar mengajar (Khoiriah \& Yunyun, 2016). Model pembelajran STAD memiliki banyak kelebihan serta mampu memotivasi serta menumbuhkan minat siswa dalam mengikuti pemebalajran. Hal ini didukung oleh hasil penelitin bahwa STAD efektif untuk meningkatan hasil belajar (Ardinata \& Dartini, 2018; Haryono, Dantes, \& Nugraha, 2016; Tama, Artanayasa, \& Satyawan, 2019). Pembelajaran kooperatif tipe STAD ini merupakan salah satu tipe dari model pembelajaran koperatif dengan menggunakan kelompok-kelompok kecil dengan jumlah anggota tiap kelompok 4-5 orang siswa secara heterogen (Trianto, 2007). STAD merupakan salah satu model pembelajaran yang efektif, mudah dan sederhana sehingga dapat diterapkan pada pembelajaran. Dengan menggunakan metode pembelajaran kooperatif tipe STAD guru tidak hanya dituntut untuk mengajar dan memberi perintah pada siswa untuk bergerak akan tetapi unsur-unsur di dalamnya harus terpenuhi seperti menganalisis membuat program dan bahan ajar, menerapkannya dan mengevaluasinya (Wadudu, Setiawan, \& Mubarok, 2019). Berdasarkan uraian di atas, maka judul penelitian yang di pilih adalah"Pengaruh Model Pembelajaran Kooperatif Tipe Student Teams Achievement Difision Terhadap Hasil Belajar Passing Sepakbola Pada Siswa Kelas VII SMP Negeri 4 Sukasada Tahun Pelajaran 2019/2020".

\section{Metode}

Jenis penelitian yang digunakan dalam penelitian ini adalah eksperimen sesungguhnya (true experimental).Dalam eksperimen murni (true experimental) merupakan pengujian variabel bebas dan variabel terikat yang dilakukan terhadap sampel kelompok eksperimen dan kelompok kontrol (Sukmadinata \& Nana, 2012). Penelitian eksperimen sesungguhnya bertujuan untuk menyelidiki kemungkinan saling hubungan sebab-akibat 
dengan cara mengenakan kepala satu atau lebih kelompok eksperimental satu atau lebih kondisi perlakuan dan memperbandingkan hasilnya dengan satu atau lebih kelompok kontrol yang tidak dikenal kondisi perlakuan (Kanca, 2010: 86

Penelitian ini dilaksanakan di kelas VII SMP Negeri 4 Sukasada tahun pelajaran 2019/2020. Pada dasarnya penelitian ini bertujuan untuk mengetahui pengaruh model pembelajaran Kooperatif tipe STAD terhadap hasil belajar Passing Sepakbola pada siswa kelompok eksperimen sedangkan kelompok kontrol diberikan pembelajaran dengan metode ceramah. Rancangan pada penelitian ini adalah Post Test Only Control Group Design (yang ditampilkan pada gambar 08 berikut).

Populasi pada penelitian ini adalah seluruh kelas VII SMP Negeri 4 Sukasada dengan jumlah keseluruhan populasi yaitu 170 siswa. Penelitian ini menggunakan simple random sampling yang digunakan pada populasi kelas yang homogen. Sampel pada penelitian adalah seluruh siswa kelas VII SMP Negeri 4 Sukasada tahun pelajaran 2019/2020 yang terdistribusi ke dalam 2 kelas yaitu: VIIB berjumlah 34 orang dan VII D berjumlah 34 orang, sehingga keseluruhan jumlah sampel penelitian adalah 68 orang. Variabel yang digunakan dalam penelitian ini ada dua jenis, yaitu variabel terikat (hasil belajar teknik dasar passing $\mathrm{n}$ ) dan variabel bebas (menggunakan kaki bagian dalam dan luar) model pembelajaran kooperatif tipe STAD dan model pembelajaran langsung). Pengumpulan data dilakukan dengan penilaian aspek kognitif oleh peneliti berupa post-test, penilaian aspek psikomotor dilakukan oleh dua evaluator. Jenis instrumen yang digunakan adalah asesmen teknik dasar passing menggunakan kaki bagian dalam dan luar. Data yang telah terkumpul dianalias menggunakan Uji t.

\section{Hasil dan Pembahasan Deskrips Data}

Data dalam penelitian ini adalah nilai hasil belajar passing menggunakan kaki bagian dalam dan bagian luar pada kelas VII SMP Negeri 4 Sukasada. Sebagai perlakuan dari model pembelajaran STAD pada kelompok eksperimen. Penelitian ini dilakukan sebanyak 4 kali pertemuan. Pada pertemuan keempat akan dilakukan tes akhir (post-tes). Penelitian ini dilakukan di SMP Negeri 4 Sukasada.

\section{Pengujian Asumsi}

Sebelum uji hipotesis dilakukan, terlebih dahulu dilakukan pengujian prasyarat terhadap sebaran data yang meliputi uji normalitas sebaran data dan uji homogenitas varians. Berikut ini diuraikan mengenai hasil pengujian normalitas sebaran data dan homogenitas varian terhadap hasil belajar teknik dasar passing sepak bola .

\section{Hasil Uji Normalitas Sebaran Data}

Pengujian normalitas sebaran data dilakukan untuk meyakinkan bahwa subjek penelitian berdistribusi normal.

Jika nilai sig pada kolom Kolmogorov-Smirnov untuk kedua kelas lebih dari 0.05 maka data kedua kelas berasal dari populasi yang berdistribusi normal. Nilai sig untuk kelas VIIB dan kelas VIID adalah 0.200 dan 0.200 yaitu lebih dari 0.05 sehingga data kedua kelas berasal dari populasi yang berdistribusi normal.

\section{Hasil Uji Homogenitas Varians}

Uji homogenitas varians antar kelompok dilakukan dengan bantuan SPSS 16.00 for Windows dengan menggunakan Levene's Test Of Equality Error Variance. Hipotesis statistik yang diuji dalam pengujian homogenitas adalah sebagai berikut:

$H_{o} \quad$ : variansi pada setiap kelompok adalah sama (homogen) 
$H_{a} \quad$ : variansi pada setiap kelompok tidak sama (tidak homogen)

Dengan kriteria pengujian yang digunakan adalah terima $H_{o}$ jika nilai $p>0,05$ dimana data memiliki varians yang sama apabila angka signifikansi yang dihasilkan lebih dari 0,05. Data yang dianalisis adalah skor posttest. Rangkuman hasil perhitungan homogenitas data menggunakan SPSS 16.00 for Windows dapat dilihat pada Tabel 2 berikut.

Tabel 2. Hasil Uji Homogenitas Varians

\begin{tabular}{llcccc}
\hline & & Levene Statistic & df1 & df2 & Sig. \\
\hline hasil & Based on Mean & & 2.793 & 166 & .099 \\
belajar & Based on Median & & 2.832 & 166 & .097 \\
& $\begin{array}{l}\text { Based on Median and with } \\
\text { adjusted df }\end{array}$ & 2.832 & & 165.559 & .097 \\
& Based on trimmed mean & 2.796 & & 166 & .099 \\
\hline
\end{tabular}

Berdasarkan Tabel 2, hasil uji Levene's Test of Equality of Error Variances menunjukkan bahwa untuk hasil belajar passing sepak bola siswa taraf signifikansi 0,099 . Bila ditetapkan taraf signifikansi 0,05 maka nilai sig. lebih besar dari taraf signifikansi yang ditetapkan. Dengan demikian hipotesis nol diterima. Artinya, semua kelompok data memiliki varians yang sama (homogen).

\section{Pengujian Hipotesis}

Setelah diperoleh hasil uji prasyarat analisis data, dilanjutkan dengan pengujian hipotesis penelitian $\left(\mathrm{H}_{\mathrm{a}}\right)$ dan hipotesis nol $\left(\mathrm{H}_{\mathrm{o}}\right)$. Pengujian hipotesis tersebut dilakukan dengan menggunakan Independent Samples Test bantuan SPSS 16.00 for Windows. Hasil analisis dengan Uji-t disajikan pada Tabel 3 berikut ini :

Tabel 3. Ringkasan Analisis Uji-t Dengan Menggunakan SPSS 16.00 for Windows

\begin{tabular}{|c|c|c|c|c|c|c|c|c|c|c|}
\hline & & $\begin{array}{l}\text { Leven } \\
\text { for Eq } \\
\text { Varian }\end{array}$ & $\begin{array}{l}\text { 's } 1 \\
\text { dality } \\
\text { ces }\end{array}$ & & $t$ for $\mathrm{E}$ & quality & of Mean & & & \\
\hline & & & & & & & & & $\begin{array}{l}95 \% \mathrm{C} \\
\text { Interval } \\
\text { Differe }\end{array}$ & $\begin{array}{l}\text { Confidence } \\
\text { of the } \\
\text { nce }\end{array}$ \\
\hline & & $\mathrm{F}$ & Sig. & $\mathrm{T}$ & Df & $\begin{array}{l}\text { Sig. } \\
(2- \\
\text { tailed) }\end{array}$ & $\begin{array}{l}\text { Mean } \\
\text { Differe } \\
\text { nce }\end{array}$ & $\begin{array}{l}\text { Std. } \\
\text { Error } \\
\text { Differe } \\
\text { nce }\end{array}$ & Lower & Upper \\
\hline hasil & Equal & 2.793 & .099 & - & 66 & .000 & - & 1.3634 & - & _ \\
\hline belaja & variances & & & & & & 28.921 & 0 & 31.643 & 26.19906 \\
\hline $\mathrm{r}$ & assumed & & & 13 & & & 18 & & 29 & \\
\hline & Equal & & & - & 62.9 & .000 & - & 1.3634 & - & 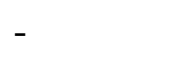 \\
\hline & variances & & & & 31 & & 28.921 & 0 & 31.645 & 26.19658 \\
\hline & not assumed & & & 13 & & & 18 & & 77 & \\
\hline
\end{tabular}

Berdasarkan Tabel 3 Pada kolom sig (2-tailed) jika nilai sig < 0.05 artinya $\mathrm{H}_{\mathrm{o}}$ ditolak dan $\mathrm{H}_{\mathrm{a}}$ diterima. Nilai sig untuk uji hipotesis adalah $0.000<0.05(\mathrm{P}<0.05)$ sehingga $\mathrm{H}_{\mathrm{o}}$ 
ditolak dan $\mathrm{H}_{\mathrm{a}}$ diterima. Hasil ini menyatakan bahwa terdapat perbedaan hasil belajar passing sepak bola antara siswa yang diberi perlakuan dengan model pembelajaran STAD dengan siswa yang diberi perlakuan dengan model pembelajaran konvensional. Sehingga model pembelajaran STAD berpengaruh signifikan terhadap hasil belajar passing sepak bola pada siswa kelas kelas VII SMP Negeri 4 Sukasada.

Nilai rata-rata skor kelompok eksperimen $=77,00$ dan rata-rata skor kelompok control $=60.00$ standar deviasi dari kelompok eksperimen $=14,36$ dan standar deviasi kelompok control $=16,50$. Standar deviasi kelas eksperimen dan kelas control menunjukkan daya serap siswa pada setiap kelompok. Semakin kecil daya serap setiap kelas maka daya serap semakin merata. Kelompok eksperimen memiliki standar deviasi lebih kecil dengan demikian daya serap antara siswa satu dengan yang lain tidak jauh beda atau dapat dikatakan lebih bervariasi dibandingkan dengan kelompok control yang daya serap kurang bervariasi. Sehingga berdasarkan analisis data diperoleh bahwa terdapat perbedaan hasil belajar teknik dasar passing sepak bola kaki bagian dalam dan kaki bagian luar antara siswa yang dibelajarkan dengan model pembelajaran kooperatif tipe STAD dengan siswa yang dibelajarkan dengan model pembelajaran konvensional, ini berarti model pembelajaran kooperatif tipe STAD berpengaruh terhadap hasil belajar teknik dasar passing sepak bola kaki bagian dalam dan kaki bagian luar pada siswa.

Pembelajaran dengan model STAD ternyata efektif meningkatkan hasil belajar siswa.

Pada kelas Eksperimen saat pembelajaran berlangsung peneliti mengarahkan serta memberikan perhatian terhadap pemahaman peserta didik tentang passing menggunakan kaki bagian dalam dan kaki bagian luar dalam permainan sepakbola dengan menerapkan Model pembelajaran STAD. Pemilihan strategi pembelajaran yang tepat sangat mempengaruhi hasil belajar yang diperoleh siswa (Murtiyasa \& Hayuningtyas, 2020). Pembelajaran koperatif tipe STAD dicirikaan oleh penghargaan kooperatif daripada penghargaan individual, sehingga dalam proses pembelajarannya siswa mampu belajar saling membantu dalam kelompok kecil (Wesnawa, Yasa, \& Suputra, 2017). Pada Proses pembelajarannya siswa dikelompokkan menjadi kelompok-kelompok kecil beranggotakan empat sampai lima orang yang di desain berdasarkan perbedaan kemampuan untuk saling berdiskusi, memotivasi, membantu satu sama lain agar setiap siswa dapat belajar guna meraih hasil yang maksimal (Sofyan, 2020). Temuan penelitian ini diperkuat dengan hasil yang menyatakan bahwa bahwa penggunaan model pembelajaraan STAD berpengaruh signifikan terhadap hasil belajar siswa (Dewi \& Sumantri, 2017; Suarta \& Dkk, 2017; Suroyo, 2014; Susila, Setiawan, \& Artha, 2019; Tama et al., 2019).

Pada pembejalanran dengan model pembelajaran STAD yang menekankan tentang kerjasama kelompok, dapat memicu semangat serta motivasi siswa dalam melakukan aktivitas olahraga serta belajar untuk bekerja sama dalam kelompok dan menentukan keberhasilan kelompok, siswa juga diajarkan untuk berani mengeluarkan pendapat dalam kelompoknya sehingga tidak ada ketimpangan antara siswa yang pintar dan siswa yang kurang mampu menyerap pembelajaran. Jadi siswa ditantang untuk berani unjuk kemampuan karena keberhasilan kelompok tergantung pada keberhasilan individu sehingga tiap-tiap anggota tidak dapat menggantungkan nasib pada anggota yanglain. Keunggulan dari model pembelajarn STAD ini memperlancar aktivitas belajar siswa dalam mengikuti setiap kegiatan belajar sehingga hal ini akan berdampak terhadap kenaikan hasil belajra siswa.

\section{Simpulan}

Berdasarkan hasil analisis data dan pembahasan hasil penelitian, dapat disimpulakan terdapat hubungan yang signifikan atau meningkat baik model pembelajaran STAD yang telah diterapkan dalam pembelajaran melalui hasil belajar peserta didik berpengaruh terhadap peningkatan hasil belajar pada materi passing menggunakan kaki bagian dalam dan kaki 
bagian luar pada siswa kelas VII SMP Negeri 4 Sukasada tahun Pelajaran 2019/2020. Adapun saran yang dapat disampaikan peneliti pada penelitian ini adalah sebaga berikut: 1) Bagi guru Penjasorkes, model pembelajaran kooperatif tipe student teams achievement division (STAD) dijadikan salah satu alternatif pembelajaran yang dapat diterapkan di kelas, 2) Penelitian pada pokok pembahasan passing menggunakan kaki bagian dalam dan kaki bagian luar pada peserta didik kelas VII SMP Negeri 4 Sukasada, maka dari itu untuk mendapatkan bukti-bukti yang lebih umum dari model pembelajaran STAD diharapkan peneliti lain dapat mencoba poko bahasan lain untuk mengetahui pengaruh model pembelajaran STAD dalam pembelajraan PJOK lebih mendalam dan semakin berkembang, dan 3) Penelitian ini hanya mengukur ada atau tidaknya pengaruh model pembelajaran STAD, maka dari itu di waktu mendatang dapat dilakukan suatu penelitian untuk mengkaji sejauh mana arah pengaruh model pembelajaran STAD terhadap hasil belajar PJOK peserta didik dan semoga hasil penelitian dapat bermanfaat dan terus berkembang.

\section{Daftar Pustaka}

Aini, H. N., \& Taufiq, H. (2018). Pengaruh Model Pembelajaran Kooperatif Tipe Stad Terhadap Hasil Belajar Servis Bawah Bolavoli. Jurnal Pendidikan Olahraga Kesehatan, 6(2), 519-525.

Ardinata, I. K. R. W., \& Dartini, N. P. D. S. (2018). Pengaruh Model Pembelajaran Kooperatif Tipe STAD Terhadap Hasil Belajar Teknik Dasar Passing Bola Voli. Jurnal Penjakora, 5(1). https://doi.org/http://dx.doi.org/10.23887/penjakora.v5i1.14477

Dewi, A. I. T., \& Sumantri, M. (2017). Penerapan Model Pembelajaran Kooperatif Tipe Student Team Achievement Divisions (Stad) Untuk Meningkatkan Hasil Belajar Ipa Siswa Kelas IV Di SD No. 1 Sembung Kecamatan Mengwi Tahun Pelajaran 2016/2017. Journal of Educational Action Research, 1(2). https://doi.org/http://dx.doi.org/10.23887/jear.v1i2.12039

Hanief, Y. N., \& Sugito, S. (2015). Membentuk Gerak Dasar Pada Siswa Sekolah Dasar Melalui Permainan Tradisional. Jurnal Penelitian Pem_belajaran, 1(1), 100-113. https://doi.org/https:// doi.org/10.29407/js_unpgri.v1i1.575

Haryono, D. T. C., Dantes, K. R., \& Nugraha, I. N. P. (2016). Pengaruh Model Pembelajaran Kooperatif Tipe Student Teams Achievement Division Terhadap Hasil Belajar Pada Mata Pelajaran Gambar Teknik Manufaktur Di Kelas XI TPM 1 SMK Negeri 3 Singaraja. Jurnal Pendidikan Teknik Mesin Undiksha, 4(1). https://doi.org/http://dx.doi.org/10.23887/jjtm.v4i1.18987

Hasan, S. (2015). Pengembangan Model Permainan Gerak Dasar Lempar Untuk Siswa Kelas V Sdn Tawangargo 4 Karangploso Malang. Jurnal Pendidikan Olahraga, 4(2).

Jessicasari, A., \& Hartati, S. C. Y. (2014). Pengaruh Pola Asuh Orang Tua dan Lingkungan Sekolah terhadap Kedisiplinan Siswa Dalam Pembelajaran Pendidikan Jasmani, Olahraga dan Kesehatan (Studi pada kelas XI di SMAN 3 Sidoarjo). Jurnal Pendidikan Olahraga Dan Kesehatan, 2(3), 661-666.

Khoiriah, D. S., \& Yunyun, Y. (2016). Pengaruh Model Pembelajaran Kooperatif Tipe Team Game Tournament (Tgt) Terhadap Pembentukan Nilai-Nilai Kerjasama Dalam Pembelajaran Permainan Hoki. Jurnal Pendidikan Jasmani Dan Olahraga, 1(1), 27-37. https://doi.org/https://doi.org/10.17509/jpjo.v1i1.3661

Murtiyasa, B., \& Hayuningtyas, W. (2020). Pengaruh Strategi Pembelajaran Tipe Kooperatif Dan Kreativitas Siswa Terhadap Hasil Belajar Matematika. AKSIOMA: Jurnal Program Studi Pendidikan Matematika, 9(2), 358-368. https://doi.org/https://doi.org/10.24127/ajpm.v9i2.2765

Ngubaidillah, A. (2018). Pengaruh Media Visual Menggunakan Aplikasi Lectora Inspire 
Terhadap Hasil Belajar Peserta Didik. Jurnal Penelitian Pendidikan, 35(2).

Paramitha, S. T. (2018). Revitalisasi Pendidikan Jasmani untuk Anak Usia Dini melalui Penerapan Model Bermain Edukatif Berbasis Alam. Jurnal Pendidikan Jasmani Dan Olahraga JPJO, 3(1), 41-51.

Qomarrullah, R. (2015). Model Aktivitas Belajar Gerak Berbasis Permainan Sebagai Materi Ajar Pendidikan Jasmani. Journal of Physical Education, Health and Sport JPEHS, 2(2).

Setiawan, A. (2017). Hubungan Authentic Assessment Dengan Motivasi Belajar Pendidikan Jasmani. JUARA : Jurnal Olahraga. https://doi.org/https://doi.org/10.33222/juara.v2i2.4 1

Setiawan, A., \& Rahmat, A. (2018). Pengaruh Pembelajaran Bola Tangan Terhadap Perilaku Sosial Siswa. Jurnal Pendidikan Jasmani Dan Olahraga. https://doi.org/https://doi.org/10.17509/ jpjo.v3i1.10188

Sofyan, D. (2020). Pengaruh Model Cooperative Learning Tipe Student Teams Achievement Division Terhadap Keterampilan Lay-Up Shoot Bola Basket. Jurnal Educatio FKIP UNMA, 6(2), 690-695. https://doi.org/https://doi.org/10.31949/educatio.v6i2.740

Suarta, I. komang, \& Dkk. (2017). Pengaruh penerapan model pembelajaran kooperatif tipe Student Teams Achievement Division (STAD) Terhadap Hasil Belajar Teknik Dasar Passing Sepak Bola. Jurnal Penjakora, 8(2). Retrieved from http://ejournal.undiksha.ac.id

Sukmadinata, \& Nana, S. (2012). Metode Penelitian Pendidikan.. Bandung: PT Remaja Rosdakarya.

Suroyo, B. A. (2014). Pengaruh Penerapan Model Pembelajaran Kooperatif Tipe Student Teams Achievement Division (STAD) Terhadap Hasil Belajar Shooting Sepakbola, $2(1), 56-60$.

Suryanti, N. P. E., Kristiantari, M. G. R., \& Suadnyana, I. N. (2016). Upaya Meningkatkan Perkembangan Sosial Emosional Melalui Kegiatan Permainan Tradisional Ular Naga Pada Anak Kelompok B. E-Journal Pendidikan Anak Usia Dini UNiversitas Pendidikan Ganesha, 4(1).

Susila, G. H. A., Setiawan, G. H., \& Artha, I. K. A. (2019). Implementasi Model Pembelajaran Kooperatif Tipe Student Teams Achievement Division (Stad) Berlandasan Tat Twam Asi Untuk Meningkatkan Aktivitas Dan Hasil Belajar Teknik Dasar Passing Bola Voli. Jurnal Penjakora, 6(1), 1-10. https://doi.org/http://dx.doi.org/10.23887/penjakora.v6i1.17345

Tama, I. G. S., Artanayasa, I. W., \& Satyawan, I. M. (2019). Pengaruh Model Pembelajaran Kooperatif Tipe Student Teams Achievement Division Terhadap Hasil Belajar Passing Sepakbola. Jurnal Penjakora, https://doi.org/http://dx.doi.org/10.23887/penjakora.v6i1.17641

Trianto. (2007). Model-Model Pembelajaran Inovatif Berorientasi Konstrutivistik. Jakarta: Perpustakaan Nasional.

Wadudu, H., Setiawan, A., \& Mubarok, M. Z. (2019). Pengaruh Model Pembelajaran Student Teams-Achievement Divisions Terhadap Hasil Belajar Lari Cepat Siswa Sekolah Dasar. Jurnal Kependidikan Jasmani Dan Olahraga, 3(1), 8-16.

Wesnawa, I. M. Y. J., Yasa, I. W. A., \& Suputra, P. A. (2017). Pengaruh Model Pembelajaran Kooperatif Tipe Stad Terhadap Hasil Belajar Teknik Dasar Passing Sepakbola. Jurnal Penjakora, 8(2).

Wicaksono, \& Hendityo, G. (2019). Kreativitas Guru Penjas Terhadap Proses Pembelajaran Penjas Di Sekolah Menengah Pertama Negeri Sekecamatan Kebumen Kabupaten Kebumen 2018. Jurnal Pendidikan Kesehatan Rekreasi Vol., 5(2), 95-100. 